\title{
PAN COGITO MYŚLI PO HEBRAJSKU. O RECEPCJI POEZJI ZBIGNIEWA HERBERTA W IZRAELU
}

\author{
Katarzyna CHRISTIANUS-GILETA (Uniwersytet Warmińsko-Mazurski w Olsztynie) \\ ORCID: 0000-0001-6978-0437
}

Na przełomie lat 60. i 70. XX w. pośród tłumaczonych dzieł polskiej literatury na język hebrajski wyraźnie dominowały utwory prozatorskie ${ }^{1}$. Choć tendencja ta zaczęła powoli się zmieniać jeszcze w latach 70., przełom nastąpił dopiero dekadę później. W prasie codziennej oraz w czasopismach literackich coraz częściej zaczęły ukazywać się przekłady wierszy polskich poetów na język hebrajski, co zaowocowało również większą liczbą wydań książkowych. Na wzrost zainteresowania poezją polską w Izraelu miały wpływ dwie kwestie. Po pierwsze, izraelscy czytelnicy, na fali literackich trendów płynących z Zachodu (zwłaszcza amerykańskich), zaczęli zwracać się ku poetom zza żelaznej kurtyny. W szczególności interesująca dla nich była twórczość Zbigniewa Herberta, a także przebywającego na emigracji Czesława Miłosza ${ }^{2}$. Nie mniej ważnym powodem wzmożonego zainteresowania stała się intensywna praca wybitnych tłumaczy poezji polskiej na język hebrajski: Dawida Weinfelda i — niecałe dwadzieścia lat

${ }^{1}$ Pomiędzy 1967 a 1980 r. ukazała się tylko jedna antologia polskiej poezji - Nofim dowewim [Mówiące pejzaże] G. Uriela (Tel Awiw 1972), zawierająca utwory m.in. Natana Grossa (poety tworzącego po polsku w Izraelu), Juliana Tuwima, Leopolda Staffa, Antoniego Słonimskiego i Lucjana Rydla. W osobnych wydaniach książkowych prezentowano poezję Jerzego Ficowskiego (J. Ficowski, Michtaw le-Mark Chagall [List do Marca Chagalla], thum. J. Besser, Tel Awiw 1968), Czesława Slezàka (C. Slezàk, Karatech Jeruszalajim [Wołam Cię, Jeruzalem], wyd. dwujęzyczne, thum. A. Gilboa, Tel Awiw 1967) oraz poety dwujęzycznego - Stanisława Wygodzkiego (S. Wygodzki, Ma'acar le-corech berur [Zatrzymany do wyjaśnienia], thum. J. Chrust, Tel Awiw 1967; tenże, Bamachbo [W ukryciu], tłum. B. Tenenbaum, Tel Awiw 1970).

${ }^{2} \mathrm{O}$ recepcji twórczości Czesława Miłosza w Izraelu pisała Beata Tarnowska w artykule $\mathrm{Mi}$ łosz w Izraelu (rekonesans), Świat i Słowo 2015 nr 2 (25), s. 165-182. 
później — Rafiego Weicherta ${ }^{3}$, a także komentarze zamieszczane w najpoczytniejszych dziennikach izraelskich pióra znakomitych, często polskojęzycznych, krytyków literackich. W niektórych przypadkach recenzja utworu wyprzedzała ukazanie się przekładu.

Jednym z takich krytyków był Joram Bronowski, który trzydzieści lat przed wydaniem pierwszego przekładu Barbarzyńcy w ogrodzie Herberta, zamieścił na łamach literackiego „Masa” (dodatku do dziennika „Dawar”) jego obszerną recenzję ${ }^{4}$. Rozpoczął ją dobitną tezą, iż „Zbigniew Herbert jest bez wątpienia najważniejszym i najbardziej interesującym twórcą współczesnej literatury polskiej"s. Z jednej strony Bronowski podkreślał, że językiem poety jest polski, natomiast z drugiej pisał, że

[Herbert] jest poetą kultury ponadnarodowej. To znaczy: kultury autentycznej, a dokładniej: europejskiej [...] Herbert jest przede wszystkim człowiekiem Europy, dlatego reprezentuje też ten jedyny rodzaj autentycznych twórców w epoce takiej jak nasza, w której wąski nacjonalizm rozprzestrzenia się każdego dnia i ujawnia się w całym swym fałszu. Nie bez powodu Herbert jest bardziej znany i lepiej przyjęty na Zachodzie niż reszta polskich poetów współczesnych ${ }^{6}$.

Głos Bronowskiego nie był odosobniony. Pierwsza publikacja utworu Zbigniewa Herberta w języku hebrajskim miała miejsce w 1969 r. Na łamach dodatku literackiego „Masa” w dzienniku „Lamerchaw” zamieszczono wówczas wiersz Tren leFortinbras [Tren Fortynbrasa] w thumaczeniu Dawida Weinfelda ${ }^{7}$. Przekłady nielicznych wierszy Herberta publikowali w różnym okresie także Szalom Lindenbaum, Aviva Shavit-Władkowska i Arie Brauner, na łamach takich dzienników jak „Haarec”, „Maariw”, „Jedijot Achro-

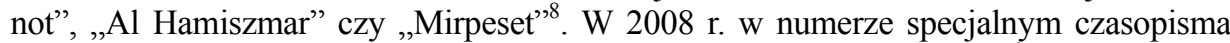
literackiego „Iton 77” ukazały się thumaczenia autorstwa Philipa Rosenau", Cwiki Sztern-

${ }^{3}$ Eli Hirsz w recenzji do antologii poezji polskiej Ha-lahat ha-adom szel ha-macuk [Czerwony blask urwiska], wydanej w 2015 r. pod redakcją i w tłumaczeniu Jonatana Barkaia, pisał: ,dzięki pracy Dawida Weinfelda i Rafiego Weicherta poezja polska ma [...] ugruntowaną i intensywną obecność w języku hebrajskim, oraz sympatię czytelników dla takich poetów jak Wisława Szymborska, Czesław Miłosz i Zbigniew Herbert"; E. Hirsz, Michtaw hitabdut [List samobójcy], Jedijot Achronot 5.01.2015, https://www.yediot.co.il/articles/0,7340,L-4748865,00.html [dostęp: 24.03.2017]; O randze poezji polskiej w Izraelu wspominał także Joram Bronowski we wstępie do specjalnej edycji czasopisma „Moznaim” Machberet polanit: mi-Mickiewicz ad Herbert. Difduf mahir [Zeszyt polski: od Mickiewicza do Herberta. Szybki przegląd], Moznaim 1999 nr 4, s. 18-19. W latach 1980-1989 przekładano także pojedyncze utwory m.in.: Adama Zagajewskiego, Karola Wojtyły, Anny Kamieńskiej, Henryka Grynberga, Jerzego Ficowskiego, Władysława Szlengela. Wszystkie fragmenty artykułów w thumaczeniu K. Christianus-Gilety.

${ }^{4}$ Joram Bronowski, obok recenzji, zamieścił także dziesięć poematów prozą Herberta we własnym tłumaczeniu, m.in.: Migdal [Wieża], Ha-tarnegolet [Kura], Klasikan [Klasyk], Hermes, kelew we-kochaw [Hermes, pies i gwiazda], Ha-gan ha-botani [Ogród botaniczny], Pil [Słoń], Jareach [Księżyc], Miszkafto szel raw-chowel [Okulary kapitana], Nisajon le-peruk ha-mitologia [Próba rozwiązania mitologii], Ajara [Miasteczko]; J. Bronowski, Barbari bagan [Barbarzyńca w ogrodzie], Dawar 9.08.1974, s. 2.

${ }^{5}$ Tamże.

${ }^{6}$ Tamże.

${ }^{7}$ Z. Herbert, Kinto szel Fortinbras, thum. D. Weinfeld, Lamerchaw 7.02.1969, s. 8.

${ }^{8}$ Informację o przekładach Szaloma Lindenbauma, Avivy Shavit-Władkowskiej, Ariego Braunera i Jaakowa Bessera zaczerpnęłam z leksykonu Literatura polska w Izraelu. Leksykon, red. K. Famulska-Ciesielska, S. J. Żurek, Kraków-Budapeszt 2012, s. 35, 40, 104, 144.

9 Philip Rosenau opublikował swoje tłumaczenia także w miesięczniku „Proza - hajarchon le-sifrut we-omanut" (lipiec 1987), [za:] Ktawej et - Mlua hatan'a [Czasopisma Pełen kosz], Maariw 28.08.1987, s. 46. 
feld, Borisa Gerusa, Jaakowa Bessera i Rafiego Weicherta ${ }^{10}$. Natomiast eseistykę Herberta thumaczyli również Joram Bronowski (fragmenty) oraz Marta i Jerzy Stankiewicz ${ }^{11}$. Największą liczbę utworów Herberta przyswoił hebrajszczyźnie jednak Dawid Weinfeld — urodzony w 1937 r. w Limanowej thumacz, historyk literatury hebrajskiej i profesor Uniwersytetu Hebrajskiego w Jerozolimie $^{12}$, i to przede wszystkim z nim kojarzona jest w Izraelu twórczość polskiego poety.

Pierwsze przekłady wierszy Herberta Weinfeld publikował w latach 70. i 80. ${ }^{13}$ na łamach popularnych dzienników, takich jak „Dawar"14 i „Maariw”,15, a w późniejszych

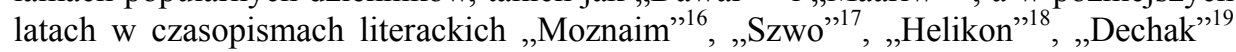

${ }^{10} \mathrm{~W}$ wydaniu specjalnym, poświęconym Herbertowi z okazji jego dziesiątej rocznicy śmierci, znalazły się następujące wiersze: Mar Cogito al ha-corech ledajek [Pan Cogito o potrzebie ścisłości], thum. P. Rosenau; Mar Cogito cofe be-chawer sze-met [Pan Cogito obserwuje zmarłego przyjaciela], thum. C. Szternfeld; Agada rusit [Bajka ruska], thum. B. Gerus; Ba-sadna [W pracowni], tłum. J. Besser, Gada [Brzeg], thum. R. Weichert. Philip Rosenau jest również autorem utworu Elegia le-mar Cogito [Elegia dla Pana Cogito], Iton 772008 nr 333-334, s. 610. Natomiast w numerze wydanym kilka miesięcy po śmierci poety zamieszczono trzy utwory Herberta z tomu Epilog burzy: Laszon chalom [Język snu], Mar Cogito. Amda Achszawit szel nefesz [Pan Cogito. Aktualna pozycja duszy], Kant. Hajamim ha-achronim [Kant. Ostatnie dni], tłum. J. Besser, Iton 771998 nr 225, s. 6-7. Besser jest także autorem przekładów dwóch innych wierszy: Le-Jehuda Amichaj [Do Jehudy Amichaja], thum. J. Besser, Iton 77 2003, nr 283, s. 2; Ba-sadna [W pracowni], thum. J. Besser, Iton $771999 \mathrm{nr}$ 234-235, s. 29; Mar Cogito mewakesz eca [Pan Cogito szuka rady], thum. J. Besser, Iton $771981 \mathrm{nr}$ 25, s. 26.

${ }_{11}^{11}$ Z. Herbert, Barbari ba-gan [Barbarzyńca w ogrodzie], Jerozolima 2005.

${ }^{12}$ Poza twórczością Zbigniewa Herberta, Weinfeld przyswajał hebrajszczyźnie utwory m.in. Seamusa Heaneya, Wisławy Szymborskiej, Czesława Miłosza, Idy Fink, Ryszarda Kapuścińskiego, Abrahama Suckewera, Ryszarda Krynickiego i Adama Zagajewskiego; zob.: Literatura polska w Izraelu, s. 166-167.

${ }^{13}$ Z. Herbert, D. Weinfeld, Listy, opr. R. Krynicki, Kraków 2009, s. 33, wszystkie przytoczone fragmenty Listów pochodzą z tego wydania (dalej: L wraz z cyfrą oznaczającą numer strony).

${ }^{14}$ Z. Herbert, Ha-har sze-mul ha'armon [Góra naprzeciw pałacu], Dawar 6.04.1980, s. 12; tenże, Haszaliach, [Posłaniec], Dawar 14.01.1983, s. 21.

${ }_{15}$ Tenże, Mar Cogito meharher al odot ha-sewel, [Pan Cogito rozmyśla o cierpieniu], Maariw 6.12.1985, s. 23.

${ }^{16}$ Tenże, Mar Cogito we-arichot ha-jamim [Pan Cogito a długowieczność], Moznaim $1986 \mathrm{nr}$ 7-8, s. 24; tenże, Duach me-ir necura [Raport z oblężonego miasta], Moznaim $1984 \mathrm{nr}$ 5-6, s. 55.

${ }^{17}$ Tenże, Szir [Wiersz], Szwo 2008, nr 19-20.

${ }^{18}$ W 2012 r. ukazały się następujące wiersze Zbigniewa Herberta w języku hebrajskim: Tfilat ower drachim szel Mar Cogito [Modlitwa Pana Cogito], Toldot Chaim [Życiorys], Ha-more le-tewa [Pan od przyrody], Mar Cogito meharher al odot ha-sewel [Pan Cogito rozmyśla o cierpieniu], Nike aszer mehaseset [Nike, która się waha], Be-studio [Studium przedmiotu], Ha-meser szel Mar Cogito [Przesłanie Pana Cogito], Ima [Matka], Kina [Tren], Elegia al histalkut ha-et, ha-dio, wehamenora [Elegia na odejście pióra, atramentu i lampy], Duach me-ir necura [Raport z oblężonego miasta], Ananim me-al Ferrara [Obłoki nad Ferrarą], Helikon 2012 nr 97. We wcześniejszych latach w czasopiśmie znalazły się także inne utwory w przekładach Weinfelda: More le-tewa [Pan od przyrody], Mar Cogito mewakesz eca [Pan Cogito szuka rady], Helikon $2013 \mathrm{nr}$ 100; Hitgalut [Objawienie], Helikon 2006 nr 72; Agartal im dmujot szchurot szel ha-kaddar Eksekias [Czarnofigurowa waza garncarza Eksekiasa], Helikon 2002 nr 45; Hasefer [Książka], Helikon 1997 nr 22; Karawan [Wóz], Helikon 1997 nr 9; Klasikon [Klasyk], Helikon 1994 nr 12; Harpaktaotaw szel Mar Cogito im musika [Przygody Pana Cogito z muzyką], Helikon $1993 \mathrm{nr}$ 8; Muto szel ari [Śmierć lwa], Helikon $1991 \mathrm{nr}$ 3, Sztej tipot [Dwie krople], Helikon $1990 \mathrm{nr} 1$.

${ }^{19}$ Z. Herbert, Ewen be-Jeruszalajim [Kamień w Jeruzalem], thum. D. Weinfeld, Dechak 2016. 
i „Iton 77,20. Ogłosił następujące zbiory utworów Herberta w języku hebrajskim: Mar Cogito we-szirim acherim [Pan Cogito i inne wiersze] (1984) ${ }^{21}$, Duach me-ir necura [Raport z oblężonego miasta] $(1990)^{22}$, Elegia le-et preida [Elegia na odejście] $(1998)^{23}$, Epilog szel se'ara [Epilog burzy] $(2005)^{24}$, a także zbiór wierszy Szirim [Wiersze], wydany w 2012 r. nakładem wydawnictwa Carmel i zawierający wszystkie jego dotychczasowe przekłady wierszy oraz kilka nowych ${ }^{25}$. Wraz z Rafim Weichertem, Weinfeld był także współautorem wydanej w $2000 \mathrm{r}$. antologii polskiej poezji Acharej mahpechot harabot [Po tylu rewolucjach], w której zamieszczono czternaście wierszy Herberta ${ }^{26}$. W najnowszej antologii Dabur meguszam joszew al perach [Jak trzmiel niezgrabny siadł na kwiecie] z 2019 r., noszącej tytuł zaczerpnięty z pierwszych wersów wiersza Herberta $O$ thumaczeniu wierszy, znalazło się osiem wierszy, w przeważającej części pochodzących z archiwum poety ${ }^{27}$.

Począwszy od lat 80., twórczość Zbigniewa Herberta - podobnie jak Czesława Miłosza, a później też Wisławy Szymborskiej, czyli autorów tworzących tzw. polską szkołę poezji - cieszyła się w Izraelu dużym zainteresowaniem odbiorców. Joram Bronowski w recenzji hebrajskiego przekładu Martwej natury z wędzidlem nazwał ten „,miłoszowsko-herbertowski kierunek [...] szkołą holenderskiego realizmu w poezji ${ }^{28}$. W tekstach krytyczno-literackich na temat twórczości Herberta niejednokrotnie pojawiało się nazwisko Miłosza, znanego izraelskim czytelnikom najpierw dzięki pierwszym thu-

${ }^{20}$ Tenże, Apollo we-Marsjas [Apollo i Marsjasz], thum. D. Weinfeld, Iton $772019 \mathrm{nr}$ 405, s. 102; tenże, Mar Cogito meharher odot hadam [Pan Cogito myśli o krwi], thum. D. Weinfeld, Iton $771991 \mathrm{nr}$ 135-136, s. 29; tenże, Mar Cogito mesaper al pituj Spinoza [Pan Cogito opowiada o kuszeniu Spinozy], Merom ha-malot [Ze szczytu schodów], thum. D. Weinfeld, Iton 771989 nr 115-116, s. 27.

${ }^{21}$ Tenże, Mar Cogito we-szirim acherim [Pan Cogito i inne wiersze], Tel Awiw 1984.

${ }^{22}$ Tenże, Duach me-ir necura [Raport z oblężonego miasta], Tel Awiw 1990. Ten tomik, opublikowany z okazji festiwalu poezji w Jerozolimie, na którym miał być obecny Zbigniew Herbert, ukazał się dwa lata przed jego pierwszym polskim wydaniem. G. Moked, Ramzor [Sygnalizacja], Moznaim 1990, nr 5, s. 33.

${ }^{23}$ Tenże, Elegia le-et preida [Elegia na odejście], Tel Awiw 1998.

${ }^{24}$ Tenże, Epilog szel se'ara [Epilog burzy], Tel Awiw 2005.

${ }^{25}$ Tenże, Szirim [Wiersze], Jerozolima 2012.

${ }^{26}$ D. Weinfeld, R. Weichert, Acharej mahpechot rabot: miwchar min ha-szira ha-polanit szeacharej 1945 [Po tylu rewolucjach: wybór poezji polskiej po 1945 roku], Jerozolima 2000. Znajdują się w nim m.in. wiersze: Nis'a le-Krakow [Podróż do Krakowa], Batej parwar [Domy przedmieścia], Hathom szel Mar Cogito [Przesłanie Pana Cogito]. Zbiór opatrzony został posłowiem Jorama Bronowskiego. Warto wspomnieć także o antologii Samuela Schepsa z 1989 r., zawierającej kilka wierszy Herberta. W tomie tym Scheps posłużył się już wcześniej publikowanymi przekładami; zob. Sz. Szeps, Sifrut polanit bi-lwusz iwri. Djokanej sofrim, polanim wi-jehudim bire’i miwchar jecirotehem ha-meturgamot [Literatura polska w hebrajskiej szacie. Portrety pisarzy polskich i żydowskich w świetle wyboru thumaczeń ich twórczości], Jerozolima 1989.

${ }^{27}$ Są to: Gluja me-Adam Zagajewski [Widokówka od Adama Zagajewskiego], Szachmat [Szachy], Masa'ot nefesz [Marzenia], Ewen be-Jeruszalaim [Kamień w Jeruzalem], Tfilat erew kcara [Krótka modlitwa wieczorna], Malchutej ha-awiona [Moje biedne królestwo jeszcze ciebie bronię...], Ha-mus szel Mar Cogito [Kalectwo Pana Cogito], Kibusz Bastilia [Oblężenie Bastylii]; Zob. Dabur meguszam joszew al perach. Tirgumej szira [Jak trzmiel niezgrabny siadł na kwiecie. Przekłady poezji], thum. D. Weinfeld, Ramat Gan 2019.

${ }^{28}$ J. Bronowski, Ha-realizm ha-holandi szel ha-szira ha-polanit [Holenderski realizm polskiej poezji], Haarec 31.10.1997, s. 2. 
maczeniom wiersza Campo di Fiori ${ }^{29}$, a następnie pojawiającym się w latach 70. w izraelskiej prasie przekładom kolejnych wierszy. Pierwsze książkowe wydanie wierszy Miłosza w języku hebrajskim nastąpiło jednak dopiero rok po otrzymaniu przez niego Nagrody Nobla ${ }^{30}$. Kwestię pominięcia Herberta przez Komisję Noblowską przy przyznawaniu tego wyróżnienia najdobitniej poruszył izraelski poeta, krytyk i eseista - Natan Zach. We wstępie do jednego z numerów redagowanego i wydawanego przez siebie poetyckiego almanachu „Hine”, pisał: „Oto jeden z wielkich współczesnej poezji światowej. Ktoś, kto już od nas - czytelników — otrzymał Nagrodę Nobla, nawet jeśli nie została mu przyznana przez upolityczniony komitet w Sztokholmie"31.

Ten szesnasty zeszyt almanachu stał się dla izraelskiego literaturoznawcy, Drora Bursteina, nieodłącznym elementem wszystkich jego podróży, co miało być „,ezoterycznym hołdem oddawanym duchowi poety”. Burstein wyznał także, że w księgarni, w której nie ma Herberta, „nie kupi żadnej książki”,32.

W zatytułowanym Recepcja Herberta w Izraelu posłowiu do zbioru korespondencji pomiędzy Herbertem a Weinfeldem, Weinfeld pisał o „dziesiątkach recenzji i artykułów o Herbercie, wieczorach poświęconych Herbertowi w tych latach, zawsze w pełnych salach, i - co może najważniejsze - dziesiątkach odniesień do jego poezji w tekstach różnych pisarzy, w różnych formach, albo jako cytaty albo jako motta, albo jako aluzje" ${ }^{33}$. Co więcej, inspiracja poezją Herberta pojawiała się w twórczości młodych poetów izraelskich — zauważalna była „w [ich] dykcji, wyważonej tonacji, powściągliwości, umiarkowanym użyciu metafory, aktualizacji przeszłości oraz ironii” [L: $35-36]^{34}$. Zdaniem Jorama Bronowskiego, takimi poetami byli na przykład Yosef Szaron czy Uzi Behar ${ }^{35}$.

Poetę i tłumacza łączyła wieloletnia znajomość, czego świadectwem jest ich korespondencja, istniejąca od maja 1984 r. aż do marca 1997 r. Zbigniew Herbert, w reakcji na otrzymanie od Juliana Stryjkowskiego pierwszego tomiku swoich wierszy, przełożonych na język hebrajski (Mar Cogito we-szirim acherim), wysłał do Weinfelda list z podziękowaniami za tłumaczenie [L: 7]. Ze względu na zły stan zdrowia Herberta oraz polityczne perturbacje w Polsce, do spotkania doszło dopiero siedem lat później ${ }^{36}$.

${ }^{29}$ Pierwsze thumaczenie wiersza Campo di Fiori ukazało się w antologii Mima'amakim. Szirim ha-getto [Z otchłani. Wiersze getta] z 1946 r. w thumaczeniu Beniamina Tenebaum-Tenego. $\mathrm{W}$ tym samym roku opublikowano również tłumaczenie Jaakowa Orlanda w tygodniku „Hed Jeruszalaim" [Echo Jerozolimy]. Kolejne przekłady wiersza, w tym Jorama Bronowskiego, pojawiły się dopiero pod koniec lat 70. w dzienniku „Haarec” (14.09.1979); za: B. Tarnowska, Miłosz, s. 168-169.

${ }^{30}$ Tamże, s. 169.

${ }^{31}$ Z. Herbert, Szirim [Wiersze], thum. D. Weinfeld, pod red. N. Zach, Hine $1996 \mathrm{nr} 16$.

${ }^{32}$ D. Burstein, Ruchot ha-refa'im szel chanujot sfarim, Mosaf Sfarim 4.10.2006, s. 16.

${ }^{33}$ D. Weinfeld, Recepcja Herberta w Izraelu, [w:] Z. Herbert, D. Weinfeld, Listy, s. 34. Skrócona wersja tego tekstu została wygłoszona przez prof. Dawida Weinfelda na zorganizowanej przez Instytut Książki sesji Ocalone w thumaczeniu, 30 października 2008 r. w Collegium Maius Uniwersytetu Jagiellońskiego w Krakowie.

${ }^{34} \mathrm{O}$ znaczeniu poezji Herberta i Miłosza w Izraelu pisali m.in. M. Maszaw (lit. pseud. Mosze Ben-Szaula), Eli Hirsz czy Joram Bronowski; zob. M. Maszaw, Gmi'ot achadot le-atid [Kilka łyków za przyszłość], Maariw 13.04.1984, s. 38; E. Hirsz, Dawid Weinfeld, Iwrut, michbar tirgumej szira [Dawid Weinfeld, Hebraizacja, wybór przekładów poezji], Jedijot Achronot 18.01.2013, http://elihirsh.com/?p=4641 [dostęp: 24.03.2018];

${ }^{35} \mathrm{~J}$. Bronowski, Ha-realizm ha-holandi.

${ }^{36}$ Zbigniew Herbert był zapraszany do Izraela już wcześniej, na organizowany w Jerozolimie przez Jehudę Amichaja pierwszy Międzynarodowy Festiwal Poezji w „Mishkenot 
Poeta odbył wówczas podróż do Izraela, aby odebrać Nagrodę Jerozolimy, jedyną międzynarodową nagrodę izraelską $w$ dziedzinie literatury [L: 39] $]^{37}$. Swój pozytywny stosunek do Izraela wyrażał między innymi w liście do Weinfelda z 9 maja 1984 r., pisząc: „wszystko, co dotyczy Izraela, żywo mnie obchodzi. Łowię wieści, zbieram książki (niestety nie znam hebrajskiego) i uważam się za przyjaciela Pana kraju” [L: 7]. Rok później, w lutym 1985 r., donosił:

O wydaniu książki w Izraelu nawet nie marzyłem i jestem szczęśliwy, że dzięki Panu ukazała się ona w kraju, który jest mi bliski, i to z głębszych powodów. Po prostu żeby nie popadać w sentymentalizm — jest częścią mojej duchowej Ojczyzny [L: 11].

W czasie podróży, którą Herbert wspominał jako „wzbogacającą, a nawet absolutnie konieczną" [L: 26$]^{38}$, miał on sposobność, żeby spotkać się z izraelskimi poetami: Jehudą Amichajem ${ }^{39}$, który w przeddzień uroczystości wręczenia Nagrody Jerozolimy poprowadził jego spotkanie poetyckie w Jerozolimie i któremu zadedykował później jeden z wierszy w tomie Rovigo (1992) [L: 16$]^{40}$, jak również z Jakubem Rotblitem ${ }^{41}$ i Dennisem Silkiem ${ }^{42}$. Owocem przyjaźni z Amichajem, a także z innym izraelskim poetą, Danem Pagisem [L: 22, 60] ${ }^{43}$, poznanym przez Herberta podczas festiwalu Poetry International w Rotterdamie w 1976 r., miało być ogłoszenie wyboru ich wierszy w przekładzie na język polski [L: 24]. Herbert zdążył przetłumaczyć cztery pierwsze części poematu Dana Pagisa Dwanaście twarzy szmaragdu. Wraz z własnoręcznie narysowanymi portretami tego poety oraz dedykowanym mu wierszem (Szukam wierszy Dana Pagisa), zachowały się one w archiwum poety ${ }^{44}$.

Sha'ananim" w Jerozolimie, który odbył się w lutym 1990 r. Postępująca choroba zmusiła poetę do odwołania swojego przyjazdu; Z. Herbert, D. Weinfeld, Listy, s. 13, 48; M. Reyzel, Tachanat ruach [Wiatrak], Maariw 19.12.1989, s. SC6.

${ }^{37}$ Jerusalem Prize for the Freedom of the Individual in Society to nagroda przyznawana co dwa lata pisarzom, którzy w swojej twórczości poruszają kwestię praw człowieka; zob. A. Franaszek, Pan Cogito, [w:] Herbert. Biografia, t. 2, Kraków 2018, s. 649.

${ }^{38} \mathrm{~W}$ niniejszym artykule pomijam polityczne wątki, związane m.in. z publikacją w „Jerusalem Post", wskutek której Herbert na krótki okres zabronił wydawania swoich wierszy w Izraelu; Zob: tamże, s. 654, 655-658.

39 Jehuda Amichaj (1924-2000), wybitny poeta izraelski, który jako pierwszy wprowadził do poezji nowohebrajskiej język potoczny. Opublikował piętnaście tomów poezji, dwie powieści i kilka książek dla dzieci. Z Herbertem spotkał się w 1967 r. w Londynie oraz w 1988 r. w Amsterdamie. O relacji „bratnich dusz” między Amichajem a Herbertem pisała m.in. Janina Katz; zrelacjonowała m.in. rozmowę z państwem Amichaj, która miała miejsce w Kopenhadze tuż po wręczeniu Herbertowi Nagrody Jerozolimy w 1991 roku: „,Państwo Amichaj] mówili o polskim poecie z podziwem, troską i czułością, jakby był ich dzieckiem”; Z. Herbert, D. Weinfeld, Listy, s. 16; J. Katz, List z Kopenhagi, Znak 1997 nr 3 (502), s. 163-166; A. Franaszek, Pan Cogito, s. 650.

${ }^{40}$ Z. Herbert, Do Jehudy Amichaja, [w:] Rovigo, Wrocław 1992; wiersz został przetłumaczony później na hebrajski przez Szaloma Lindenbauma: Z. Herbert, Le-Jehuda Amichaj, thum. Sz. Lindenbaum, Moznaim 1993 nr 3, s. 2.

${ }^{41}$ Jakub Rotblit (ur. 1945), poeta i pieśniarz izraelski, a także dziennikarz, twórca znanej w Izraelu Pieśni pokoju (1967); http://www.rotblit.co.il/bio.htm [dostęp: 24.03.2018].

42 Dennis Silk (1928-1998), poeta anglojęzyczny, który mieszkał w Izraelu; Z. Herbert, D. Weinfeld, Listy, s. 28.

${ }^{43}$ W czasie festiwalu Herbert przeczytał swój wiersz Pan Cogito szuka rady, poświęcony rabbiemu Nachmanowi z Bracławia; zob.: J. A. Gilboa, Echad min „Ha-ja'ar Halochem” [Jeden z „Walczącego lasu”], Maariw 15.04.1977, s. 59C.

${ }^{44}$ R. Krynicki, Od wydawcy, Kwartalnik Artystyczny 2009 nr 2 (62), s. 7; D. Weinfeld, Hametargemim ha-meatim mi-iwrit ma'adifim letargem proza: ra'ajon im Ryszard Krynicki [Nie- 
Zbigniew Herbert, który wysoko cenił wkład Weinfelda w popularyzację jego utworów w języku hebrajskim, o pracy translatorskiej tego izraelskiego tłumacza dowiedział się dopiero po wydaniu w Izraelu tomiku Mar Cogito we-szirim acherim [L: 7, 12]. Translatorski kunszt Weinfelda ${ }^{45}$ podkreślali także izraelscy krytycy literaccy, między innymi Erez Schweizer, który w artykule Szirim szel Zbigniew Herbert [Wiersze Zbigniewa Herberta] przywołał słowa Natana Zacha, mówiące o tym, że „nie każdy poeta dostaje tłumacza podobnego do siebie”. Schweizer dodawał: „nie każdy czytelnik, nie każdy język" "46. Podobnie Eli Hirsz w artykule Iwrut [Hebraizacja] stwierdził, że wpływ tłumaczeń Dawida Weinfelda jest być może „największy ze wszystkich tłumaczy hebrajskich ostatnich dziesięcioleci" ${ }^{47}$ i dzięki temu Czesław Miłosz i Zbigniew Herbert stali się ,"czołowymi poetami izraelskimi”,"48.

Dawid Weinfeld jest także autorem jednego z pierwszych w Izraelu komentarzy krytycznoliterackich poświęconych poezji Zbigniewa Herberta. W posłowiu do Pana Cogito, opublikowanym także jako esej Ha-dimiun ha-mehapes et ha-seder: al szirato szel Zbigniew Herbert [Wyobraźnia szukająca porządku: o poezji Zbigniewa Herberta] $]^{49}$ w czasopiśmie „Moznaim” w 1983 r., podkreślił wyjątkowość twórczości Herberta na tle poezji światowej. Wedle słów Weinfelda, poezję autora Pana Cogito cechuje „oryginalny intelekt, wyczucie proporcji i niezwykłej powściągliwości, co jest rzadkim atutem w naszym kręgu kulturowym". Natomiast poetycki styl Herberta Weinfeld oceniał następująco:

[Dykcja] realizowana jest u Herberta na przykład poprzez równowagę między poczuciem alienacji a poczuciem przynależności, między etosem humanistycznym a etosem patriotycznym. Jest to cel Herberta: nie naruszyć równowagi między maską a prawdziwą twarzą, dystansem a zaangażowaniem, obserwacją a osądem, patosem a lakonicznością, prostotą a wyrafinowaniem, bezpośredniością stylu a alegoryczną stylizacją ${ }^{50}$.

Te szczególne cechy odróżniały twórczość Herberta od trendów poetyckich panujących w Izraelu na przełomie lat 70. i 80., dlatego Weinfeld konstatował:

Herbert nie zagłębia się w prześladujące go drobne problemy i smutki, nie eksponuje prywatnych żalów i daleki jest od narcystycznego dramatyzowania, jakie można odnaleźć w wielu dziełach tworzonych obecnie w Izraelu. On nie zmusza czytelnika, jak stwierdził jeden z jego krytyków, aby był psychoanalitykiem, którego zadaniem jest rozszyfrowywanie meandrów umysłu poety. Szczerość Herberta jest raczej intelektualna niż emocjonalna ${ }^{51}$.

liczni tłumacze z hebrajskiego wolą thumaczyć prozę: wywiad z Ryszardem Krynickim], Iton 77 2009 nr 337-338, s. 30.

${ }^{45}$ Praca translatorska Weinfelda została, „za promocję polskiej literatury na świecie”, uhonorowana Nagrodą Fundacji Kultury Polskiej (1995) oraz Polskiego PEN Clubu (2006); zob. m.in.: [Bronisław Mamoń], Nagroda dla Weinfelda, Tygodnik Powszechny 1995 nr 22, s. 12, cyt. za: B. Tarnowska, Miłosz w Izraelu, s. 175.

${ }^{46}$ E. Schweizer, Szirim szel Zbigniew Herbert: ed ohew [Wiersze Zbigniewa Herberta: czułego świadka], Haarec 13.02.2012, https://www.haaretz.co.il/literature/poetrybelongings/1.1636452 [dostęp: 24.03.2018] (dalej: Sch).

${ }^{47}$ E. Hirsz, Dawid Weinfeld, Iwrut, michbar tirgumej szira.

48 Tamże; por.: C. Szternfeld, Intimiut im ha-necach [Intymność z wiecznością], Iton 772008 nr 333-334, s. 46; A. Miszol, Ha-meridianim szel ha-sifrut [Meridiany literatury], tamże, s. 33.

${ }^{49}$ D. Weinfeld, Ha-dimiun ha-mehapes et ha-seder: al szirato szel Zbigniew Herbert [Wyobraźnia szukająca porządku: o poezji Zbigniewa Herberta], Moznaim 1983 nr 5, s. 34-36.

${ }^{50}$ Tamże, s. 34.
${ }^{51}$ Tamże, s. 35. 
Weinfeld zaprzeczał, jakoby na sposób opisywania przeszłości przez Herberta miała wpływ panująca w epoce PRL-u cenzura. Wskazywał raczej na kilka formatywnych elementów, takich jak ,wizja sztuki, stosunek do przeszłości oraz związki z dziedzictwem kulturowym, ${ }^{, 52}$. Zauważał także, że „,przeszłość jest u Herberta kryterium tradycyjnym i estetycznym lub, ściślej biorąc, tradycyjno-estetycznym, bez dzielącego je spójnika «i»»". Weinfeld nie zaliczał Herberta do poetów, którzy tworzą „,własny” język, z wyraźnymi i charakterystycznymi dla twórczości niektórych autorów cechami. Składnia i słownictwo jego wierszy „dalekie są zarówno od naruszania normy językowej, jak i od poetyckiego banału". Natomiast brak interpunkcji świadczy, w ocenie Weinfelda, o klarowności poezji, nie zaś o „modernistycznej manierze”, i nie przynosi „wolnego przepływu obrazów”, ale jest raczej wskazówką dla czytelnika, ,jak czytać utwór" ${ }^{33}$. Weinfeld nie twierdził jednak, że cechy te konstytuują poezję Herberta jako „ubogą", wręcz przeciwnie:

Czasem ciężko uwolnić się od wrażenia, że poeta narzuca sobie ascetyczną prostotę, kiedy powstrzymuje się od wykorzystywania bogactwa języka i brzmienia. Herbert wybiera przejrzystość semantyczną oraz dokładne i jednoznaczne słownictwo. Złożoność i napięcie w jego wierszach oparte są na innych wartościach, takich jak przejście $\mathrm{z}$ obserwacji i opisu (sytuacja zawsze jest jasno zarysowana) do konfliktu wartości ${ }^{54}$.

Rok po ukazaniu się hebrajskiego przekładu tomiku Pan Cogito i inne wiersze, Dawid Weinfeld w listach zapewniał Herberta o pozytywnej recepcji jego poezji w Izraelu:

Pańska poezja została przyjęta w Izraelu z entuzjazmem. Właściwie jest ona znana tu od lat, bo wiersze początkowo były drukowane w czasopismach. Teraz dotarły do szerszych kręgów, a przede wszystkim do tych, na których mi najbardziej zależy, młodych hebrajskich poetów. W radiu nadawano codziennie przez dwa tygodnie wiersze i godzinna audycja radiowa o Pana twórczości znajduje się w przygotowaniu (z moją współpracą) [L: 9-10 $]^{55}$.

Potwierdzenie tych słów można odnaleźć między innymi w tekście Meszorer hacham we-acuw [Poeta mądry i smutny] Szaloma Rozenfelda, w którym autor określił poezję Herberta jako ,połączenie emocji i intelektu, romantyki i wyrafinowania”, a samego

52 Tamże; por.: D. Weinfeld, Ha-metargemim ha-meatim mi-iwrit ma'adifim letargem proza: ra'ajon im Ryszard Krynicki, s. 29.

${ }^{53}$ Odmienne zdanie reprezentuje izraelski poeta, thumacz, krytyk i wydawca literackiego czasopisma „Dehak” Jehuda Vizan, który w 2019 r. w recenzji do wyboru wierszy Weinfelda Dabur meguszam joszew al perach napisał: „Nie ma doprawdy znaczenia, czy tekst jest wierszowany czy nie, interpunkcja również nie pomoże — proza pozostanie prozą". Przykład Herbertowskiej poezji posłużył Vizanowi jako argument, jakoby Weinfeld wybierał do thumaczenia poezję bez rymów, bliską prozie, a poprzez niepośledni wpływ przekładanej przez tłumacza poezji polskiej na izraelskich poetów, szkodził poezji hebrajskiej; J. Vizan, Popolonizm: lama ha-szira ha-polanit ha-meturgemet mazika la-szira ha-iwrit ha-achszawit [Popolonizm: dlaczego tłumaczenia poezji polskiej szkodzą współczesnej poezji hebrajskiej], Haarec 27.09.2019, https://www.haaretz.co.il/literature/poetry/.premium-REVIEW-1.7889412 [dostęp: 12.12.2019].

${ }_{54} \mathrm{D}$. Weinfeld, Ha-dimiun ha-mehapes, s. 36.

${ }^{55}$ Wspomniana audycja radiowa to Milim sze-menasot laga'at [Słowa, które próbują dotknąć], nadana w stacji Reszet Alef 4 stycznia 1986 r., a zapowiadana jako: „Zbigniew Herbert — portret jednego z najważniejszych i najbardziej znaczących poetów w dzisiejszej polskiej poezji”; Program telewizyjny i radiowy, Maariw 3.01.1986, s. 110; poezja Herberta była też tematem audycji Milim sze-bacharti ba-szira we-proza [Słowa, które wybrałem z poezji i z prozy], wyemitowanej 8 grudnia, również w stacji Reszet Alef; zob.: Hoda'ot [Ogłoszenia], Maariw 7.12.1990, s. SC6. 
poetę jako „smutnego, który domaga się, aby swój smutek wyrażać przy pomocy mądrych słów" "56. W podobny sposób o poetyce Herberta pisał tuż po śmierci poety krytyk i tłumacz poezji Wisławy Szymborskiej, Rafi Weichert, nazywając ją ,dusznym uniwersum, gorzkim i bardzo cynicznym"57. Przeciwstawiając jego poezję twórczości Szymborskiej i Miłosza, pisał, że Herbert to ,poeta najbardziej cierpiący, któremu ostrość i trzeźwość umysłu nie pozwoliły napisać ani jednego wiersza o radości"58.

Na początku 1999 r., thumacz i krytyk Joram Bronowski w krótkim wstępie do specjalnego, poświęconego polskiej literaturze wydania literackiego czasopisma „Moznaim" podkreślał, że Izrael jest krajem, w którym twórczością takich poetów jak Miłosz czy Szymborska interesowano się na długo przed otrzymaniem przez nich Nagrody Nobla, zaś Herbert jest twórcą, który tej nagrody nie zdążył dostać, ale na którą również zasługiwał ${ }^{59}$. Zmarły trzy lata później Bronowski był — obok Weinfelda najważniejszym propagatorem poezji Herberta w Izraelu, wskazującym na istotny wpływ, jaki twórczość polskiego poety wywarła na poezję izraelską. Jak pisał:

Izraelczykom zmagającym się z problemem własnej tożsamości i ulegającym wpływom różnego rodzaju orientalizacji, Herbert poza doskonałymi i pięknymi wierszami przyniósł coś jeszcze. Uczy on nas mianowicie wierności wobec kultury zachodniej i odsyła do twórców z przeszłości: greckich i holenderskich czasów złotego wieku ${ }^{60}$.

Bronowski dowodził także podobieństwa pomiędzy poezją Herberta a poezją izraelską lat 30. XX w. Punktem stycznym było, jego zdaniem, ,pole gorzkich chwastów ironii”, przez które Herbert miał „zagościć w języku hebrajskim w sposób zupełnie naturalny”, znajdując bliższe podobieństwo z ,poetą kultury” Israelem Pinkasem niż z modernistycznym ironistą - Natanem Zachem ${ }^{61}$. Trudniej było opisać charakter tej ironii Aminadavowi Dikmanowi - thumaczowi między innymi Trenów Kochanowskiego na język hebrajski. W recenzji Lizkoro szel Mar Cogito [Pamięci Pana Cogito], Dikman z jednej strony wskazywał na problem z określeniem stylu Herberta, natomiast z drugiej — za wspólny mianownik jego wierszy uważał nieustanną tęsknotę i częste odniesienia do kultury $^{62}$.

Jedną z recenzji pierwszego zbioru wierszy, wydanego po śmierci poety Epilog szel se'ara [Epilog burzy] ${ }^{63}$, był między innymi tekst Szmuela Szetela, opublikowany w literackim czasopiśmie „Iton 77” w 2006 r. Szetel pisał o etycznym wymiarze wierszy Herberta oraz zauważał taką cechę jego poezji, jak szlachetność, objawiającą się

${ }^{56}$ Sz. Rozenfeld, Meszorer hacham we-acuw [Poeta mądry i smutny], Maariw 6.12.1985, s. 23. Rozenfeld zamieścił także wiersz Mar Cogito meharher al odot hasewel [Pan Cogito rozmyśla o cierpieniu] w thumaczeniu D. Weinfelda.

${ }^{57}$ R. Weichert, Ha-bituj ha-medujak la-achzarjut ha-enoszit [Dokładne określenie ludzkiego okrucieństwa], Maariw 18.09.1998, s. 37.

${ }^{58}$ Herbert odpierał podobne zarzuty: „Zbyt optymistycznie nastawieni do świata krytycy zarzucają mi pesymizm. Zawsze wydawało mi się to nieporozumieniem. [...] Podobnie jak ironia nie jest cynizmem, ale wstydliwością uczuć, to co z pozoru wydaje się pesymistyczne, jest stłumionym wołaniem o dobro, o pomnożenie dobra, o otwarcie sumień". Z. Herbert, Dotknąc rzeczywistości, [w:] tenże, „Mistrz z Delft” $i$ inne utwory odnalezione, oprac. B. Toruńczyk, H. Citko, Warszawa 2008, s. 161.

${ }^{59}$ J. Bronowski, Machberet polanit: mi-Mickiewicz ad Herbert, s. 18.

${ }^{60}$ Tenże, Zbigniew Herbert, 1925(!)-1998, Haarec 30.07.1998, s. 3D.

${ }^{61}$ Tamże.

${ }^{62}$ A. Dikman, Lizkoro szel Mar Cogito [Pamięci Pana Cogito], Haarec 16.12.1998, s. 10.

${ }^{63}$ Tomik w języku hebrajskim, oprócz wierszy z oryginalnego wydania Epilogu burzy, zawiera wiersze wcześniejsze, a także niepublikowane, oraz fragmenty prozy. 
w ,głębokim związku pomiędzy pisaniem a niezniszczalnym pięknem, ale też w roli poety i jego pracy twórczej na kolejnych etapach życia, które powinno być jak film, jak kolejny dowcipny komentarz"64.

W recenzji tomiku Elegia le-et preda [Elegia na odejście], opublikowanej w tym samym roku co hebrajski przekład, współpracująca z dziennikiem „Haarec” izraelska pisarka Batia Gur odnajdywała genialną siłę Herberta w ,przedstawianiu świata na opak, w podważaniu i obalaniu tradycyjnego punktu widzenia”. Pochwalała także jego postawę „realistycznego romantyka" 65 .

Pośród wielu omówień poezji Herberta w Izraelu, znajdowały się też głosy bardziej sceptyczne. Szimon Bozaglo w krótkim eseju Ma bejn ta'arowet le-tirkowet [Między mieszaniną a kombinacja], opublikowanym w 2006 r. na łamach pisma „Maariw”, twórczość polskiego poety opisuje w kontekście kultury wschodnioeuropejskiej: ,jej składniki są dobre, czasem nawet wspaniałe, ale problemem są związki pomiędzy nimi. Czuję, że wschodnioeuropejska sztuka ma tendencję do bycia nazbyt przegadaną"66.

Wiersz Podróż do Krakowa przyrównuje do wierszy niemieckiego poety Hansa Marcusa Enzensbergera, ale w przeciwieństwie do utworów Enzensbergera, „zakończenia wierszy Herberta są przegadane”. Dla izraelskiego poety i thumacza literatury antycznej twórczość autora Studium przedmiotu była raczej „,bezładną mieszaniną” niż związkiem refleksji i wrażeń, a zwyczaj ,zasypywania mądrościami” przez Herberta „,czasem męczący w swojej dydaktyczności”. Bozaglo kończy tekst nieco deprecjonującym stwierdzeniem, że „dla kogoś, kto nie czytał Miłosza, poezja Herberta będzie rodzajem rozgrzewki do czegoś prawdziwego"67.

W 2008 r., w dziesiątą rocznicę śmierci poety, w Polsce ogłoszono „Rok Herberta”. Z tej okazji literackie czasopismo „Iton 77” wydało numer specjalny poświęcony Zbigniewowi Herbertowi ${ }^{68}$. Obok thumaczeń jego wierszy, znalazły się tam między innymi utwory napisane w hołdzie polskiemu poecie, autorstwa Tuwii Ribnera, Seamusa Heaneya czy Amira Ora ${ }^{69}$. W numerze tym opublikowano także artykuł jednego $\mathrm{z}$ thumaczy Herberta, Philipa Rosenau ${ }^{70}$, w którym pisał on m.in. o moralnej postawie Herberta:

Jego polityczność wynika z antypolityczności: z prawa i obowiązku do strzeżenia oraz przestrzegania ludzkiej godności bez schlebiania kolektywnemu monstrum i bez podporządkowywania się wszelkim ,izmom”. [...] W jego poezji nie ma oczekiwania na bli-

${ }^{64} \mathrm{Sz}$. Szetel, Bone olam, lo me-atomim, ela me-sze'eriot [Świat buduje, nie z atomów, lecz z odłamków], Iton 77 2006, nr 312-313, s. 11.

${ }^{65}$ B. Gur, Ha-ecem ha-jafe mi-kol hu ze sze'ejnenu [Najpiękniejszy jest przedmiot, którego nie ma], Haarec 10.07.1998, s. 14B.

${ }^{66}$ Sz. Bozaglo, Ma bejn ta'arubat le-tirkowet [Między mieszaniną a kombinacją], Maariw 6.01.2006, s. 26. Tytułowe ta'arubat oznacza dosłownie mieszaninę, mieszankę, zaś tirkowet złożoną strukturę, kombinację, związek.

${ }^{67}$ Tamże.

${ }^{68} \mathrm{~W}$ numerze pojawiły się również przekłady twórczości m.in. S. J. Leca, J. Kochanowskiego, K. I. Gałczyńskiego, Cz. Miłosza, W. Szymborskiej, E. Lipskiej, T. Różewicza, A. Zagajewskiego, U. Kozioł, H. Grynberga oraz A. Stasiuka, a także przekłady wierszy polskich poetów młodszego pokolenia: N. Kuleszy, P. Barańskiego, K. Turaj-Kalińskiej, E. Pasewicza, M. Świetlickiego i M. Grzebalskiego; zob.: Iton 77 2008, nr 333-334.

${ }^{69}$ Zob. T. Ribner, Le-zecher Zbigniew Herbert [Pamięci Zbigniewa Herberta]; S. Heaney, Leruach ha-refa'im szel Zbigniew Herbert [Do ducha Zbigniewa Herberta], thum. na hebr. O. Peled; A. Or, Sicha im Mar Cogito [Rozmowa z Panem Cogito], Iton 772008 nr 333-334, s. 11.

${ }^{70}$ Philip Rosenau (ur. 1946), profesor matematyki i poeta. W 2011 r., w rozmowie z Joawem Itamarem podkreślił, jaką ważną postacią w jego życiu był Herbert; J. Itamar, Philip Rosenau ose cheszbon: sicha [Philip Rosenau rozważa: rozmowa], Iton 772011 nr 353, s. 38. 
skie odkupienie, a jest raczej nakaz przyzwoitego zachowywania się. Nie z powodu oczekiwania na nagrodę, lecz dlatego, że takie zachowanie definiuje człowieka ${ }^{71}$.

Autor artykułu podkreślił przede wszystkim takie przymioty jego poezji, jak równowaga stylu, umiarkowanie, zrozumiałość, oszczędność ekspresji, ironia i powściągliwość w wyrażaniu uczuć. Zauważył, podobnie jak wcześniej uczynił to Weinfeld, że ,jego poezja nie daje czytelnikowi prostych wyjaśnień, ale również nie pozostawia go samemu sobie. W ten sposób nie pozwala odbiorcy użalać się nad sobą,"72.

Wydany w 2012 r. tom Szirim, w którym Dawid Weinfeld zamieścił swoje wszystkie dotychczasowe przekłady wierszy Herberta, a także dodał kilka nowych, wywołał w Izraelu żywy oddźwięk. Decyzję o opublikowaniu tego zbioru docenił między innymi Erez Schweizer, który w recenzji Szirim szel Zbigniew Herbert: ed ohew [Wiersze Zbigniewa Herberta: czułego świadka] wyrażał przekonanie, że praca Weinfelda była „osiągnięciem wymagającym wiele czasu, dokonaniem koniecznym, i nie tylko dlatego, że większość jego wcześniejszych książek wyprzedało się dawno temu. Herbert jest pisarzem, którego pragnie się poznać dogłębnie, ciągle do niego wracać, słuchać jego jasnej myśli i oszczędnego, szlachetnego języka, i uczyć się równowagi stylu" [Sch $]^{73}$.

Schweizer wyróżnił szczególną cechę poezji Herberta, polegającą na równowadze „,pomiędzy trzeźwością widzenia a optymizmem, między konserwatyzmem a pomysłowością, między podróżą metafizycznej wyobraźni a ostrością spojrzenia, między stylem a treścią" [Sch]. Przywołał też słowa Weinfelda z 1983 r., które definiowały tę równowagę w poezji Herberta poprzez jej moralno-estetyczny charakter. Cnoty Herberta, zdaniem Schweizera, mają być remedium na zło świata i, co istotne, nie są oznaką słabości. Suchy i wolny od emocji ton sprawia, że odnosi się wrażenie pełnego dystansu, racjonalnego podejścia do świata, czy jak napisał Schweizer, parafrazując słowa zamieszczone w nagrobnej inskrypcji poety Roberta Frosta ${ }^{74}$ : ,jego stosunek do świata podobny był raczej do kłótni kochanków". Aby opisać tematykę poezji Herberta, Schweizer określił poetę ,świadkiem miłości”, pisząc:

[Herbert] przyglądał się na wojnie śmierci ofiar, śmierci swojego przyjaciela, swojej własnej zbliżającej się śmierci, i wszystkim służył jako świadek miłości, bezlitośnie realistyczny, ale czuły. [...] Herbert był czułym świadkiem. Nigdy nie starał się upiększać ludzkiej natury, dawać fałszywego pocieszenia [Sch].

Na temat Szirim wypowiedział się również Eli Hirsz, podkreślając kontemplacyjny charakter poezji Herberta, w której „to, co osobiste, pozostaje w cieniu bardziej uniwersalnych wartości, a znajomość złożonych losów tego poety podkreśla w jeszcze większym stopniu introwertyczne aspekty jego charakteru i pozwala odkryć jego poezję w całym jej pięknie" [E.H.] $]^{75}$. Eli Hirsz tłumaczył tę kontemplacyjność biograficznym doświadczeniem poety — jego poezja powstawała bowiem w cieniu komuni-

${ }^{71}$ P. Rosenau, Zbigniew Herbert - asor le-muto [Zbigniew Herbert — w dziesiątą rocznicę śmierci], Iton $772008 \mathrm{nr} 333-334$, s. 5.

${ }^{72}$ Tamże.

${ }^{73}$ Schweizer proponuje także, aby Weinfeld wydał podobny tomik, w którym zostaną zebrane utwory Czesława Miłosza. Pomysł krytyka urzeczywistnił się już w 2013 r.; zob.: Cz. Miłosz, Or jom: miwchar szirim [Światło dzienne], thum. D.Weinfeld, Ra'anana 2013.

${ }^{74}$ Robert Frost (1874-1963), jeden z czołowych poetów amerykańskich XX w. Czterokrotny laureat Nagrody Pulitzera; https://www.britannica.com/biography/Robert-Frost [dostęp: 30.04.2018].

${ }^{75}$ E. Hirsz, Zbigniew Herbert, Szirim, Jedijot Achronot 9.04.2012; http://elihirsh.com/?p=3607 [dostęp: 24.03.2018] (dalej: E.H.) 
stycznego reżimu w Polsce, a ciągłe przeciwstawianie się temu opresyjnemu systemowi stanowiło o jej sile. W opinii Hirsza, Zbigniew Herbert szukał sposobów, ażeby przesunąć bezpośredni, polityczny punkt widzenia na kwestie etyczne, kulturalne i estetyczne. Retoryka polityczna „,budziła w nim powściągliwość, gdyż była nazbyt podobna do retoryki komunistów” [E.H.]. Tak Hirsz thumaczył powstanie mitu o „klasycznej" poetyce Herberta, która czerpie inspirację z literatury i filozofii starożytnej Grecji i Rzymu, a konstytuuje się dzięki takim cechom jak umiar, równowaga oraz ironia. Choć, jego zdaniem, można te zalety przypisać wierszom autora Pana Cogito, charakteryzują one ją jedynie powierzchownie [E.H.]. Hirsz dostrzegał w poezji Herberta raczej ,patos kogoś, kto traktuje siebie jako narodowego proroka i stawia innym wysokie etyczne wymagania" [E.H.]. Zauważał także, że po powrocie Herberta z podróży do Stanów Zjednoczonych nastąpiła w nim przemiana, uwidoczniona w jego poezji, a wywołana stanem psychicznym, oscylującym pomiędzy niemocą a nadzieją. Wyrazem tej przemiany stał się tom Raport z oblężonego miasta z 1983 r. Oblężonym miastem jest Polska, która cały czas musi bronić się przed zewnętrznymi siłami okupanta oraz jego polskimi kolaborantami, i pozostaje jej tylko walka. Hirsz jednak postawił pytanie: „skoro mowa o kraju, ojczyźnie, dlaczego «miasto»? Czy nie chodziło Herbertowi o Jerozolimę z czasów starożytnego poety hebrajskiego Izajasza, która przeciwstawia się tyranii władzy zagrażającej jej zarówno od środka, jak i z zewnątrz, gdzie wszyscy są przeciwko niej”? Zdaniem krytyka, Herbert postrzegał siebie jako ,jedynego" proroka, o czym miałby świadczyć fragment wiersza: „cmentarze rosną maleje liczba obrońców / ale obrona trwa i będzie trwała do końca / i jeśli Miasto padnie a ocaleje jeden / on będzie niósł Miasto w sobie po drogach wygnania / on będzie Miasto" [E.H.]. Jednocześnie dodawał, że Herbert nie chciał widzieć siebie jako proroka w sensie symbolicznym. Choć przejął od proroków bezkompromisowość w postawie moralnej — rozeznanie pomiędzy dobrem a złem — „odrzucił obietnice odkupienia Izajasza i jego naśladowców, którzy fantazjowali o raju na ziemi niczym komuniści”. Aczkolwiek pisał w imię prawdy i sprawiedliwości, to jednocześnie wyjaśniał, że „nie ma prawdy i sprawiedliwości boskiej, i dlatego nie ma innego wyjścia jak realizowanie ich środkami ludzkimi, kruchymi, podatnymi na porażkę" [E.H.]. Jako źródło etycznej postawy Herberta Eli Hirsz wskazuje jego pełną dumy i bólu świadomość sprzeczności: „[świadomość] nie tylko granic niby-proroczych aspiracji, ale także związanych z tym szaleństwem i mocą" [E.H.].

Natomiast w recenzji zamieszczonej w 97. numerze czasopisma „Helikon” z 2012 r., który zawierał między innymi przekłady wierszy Miłosza i Herberta, Hirsz podkreślił znaczenie twórczości tych poetów dla ostatnich dwóch pokoleń izraelskich czytelników, a także to, że dla wielu z nich te przekłady funkcjonowały jako ,rodzaj czytelniczej wskazówki albo wiarygodnego kryterium dla «poezji», jaką powinno się dzisiaj pisać". Powód tak wysokiej pozycji twórczości Miłosza i Herberta w Izraelu Hirsz opisał, cytując słowa Bursteina ze wstępu do Hebraizacji: ,[jest to poezja] przywracająca zapomniane możliwości wiersza, który mówi coś w sposób bezpośredni i zasadniczy o świecie, i zwraca się do tego świata, wyzbywając się krytycyzmu oraz przesadnej subiektywizacji”. To właśnie te trzy cechy — kontemplacyjność, stosowanie „,właściwej miary” oraz niechęć do egzaltacji — charakteryzują, w opinii Hirsza, poezję Herberta, a także Miłosza. Jednocześnie Hirsz podkreślił, że ta poetycka powściągliwość nie miałaby wartości, gdyby nie warstwa quasi-ironiczna lub quasi-realistyczna, która służy jako „tło wielkich poetyckich żądz i dobrze pojęte skupienie na własnej doskonałości",76.

\footnotetext{
${ }^{76}$ E. Hirsz, Dawid Weinfeld, Iwrut, Miwchar tirgumej szira.
} 
Krytyka literacka w Izraelu o wielu aspektach twórczości Herberta wypowiada się w podobnym tonie co krytyka zachodnia. Zarówno odbiorców zachodnich, jak i izraelskich, pociągało zastąpienie nadwrażliwego lirycznego ,ja” walką o wartości etyczne $\mathrm{Z}$ negującym te wartości światem ${ }^{77}$. $Z$ kolei tłumacze cenili sobie $\mathrm{w}$ jego poezji uniwersalność, która odzwierciedlała się w wyjątkowej ,przekładalności, ${ }^{, 78}$.

Różnice w podejściu krytycznym uwidaczniają się nieco w ujęciu „polityczności”: na Zachodzie podkreślano wpływ ówczesnych wydarzeń na twórczość poety i na ogół jego poezję rozpatrywano $\mathrm{w}$ kontekście politycznym ${ }^{79}$, natomiast krytykom izraelskim bliższe było stanowisko Stanisława Barańczaka, który pisał, że „,sensy polityczne, konkretne historyczne i autobiograficzne - trzeba przy czytaniu poezji Herberta brać między innymi pod uwagę" ${ }^{\prime 0}$. Wprawdzie wątek polityczny nie był bagatelizowany przez izraelskich interpretatorów, lecz przy omawianiu twórczości Herberta nie stanowił głównej kwestii: podkreślano raczej „antypolityczność” i skupianie się na ogólnych zasadach moralnych $^{81}$. Podobnie jeden $\mathrm{z}$ zachodnich krytyków, angielski poeta i pisarz Al Alvarez pisał, że Herbert jest „,polityczny poprzez permanentne i czujne trwanie w opozycjiı" ${ }^{82}$.

Z powyższego, choć niepełnego ${ }^{83}$, przeglądu opinii krytycznych w Izraelu można wnioskować, że twórczość Zbigniewa Herberta — podobnie jak Czesława Miłosza ${ }^{84}$ została tam w pełni doceniona, a także odcisnęła piętno na rozwoju współczesnej poezji izraelskiej w języku hebrajskim ${ }^{85}$. Charakterystyczne cechy poezji Herberta, takie jak ironia, kontemplacyjność, skupienie się na kwestiach etycznych czy równowaga stylu, znajdowały zatem uznanie nie tylko w Europie i w Stanach Zjednoczonych. Dzięki wysiłkowi wybitnego thumacza - Dawida Weinfelda — Zbigniew Herbert zdobył uznanie izraelskich czytelników, którzy docenili wyjątkowe cechy jego poezji, a dla wielu izraelskich poetów stał się wzorem godnym naśladowania.

${ }^{77}$ A. Brajerska-Mazur, ,,Polityczność”, ,,polskość” $i$,, uniwersalność” wierszy Herberta w przekładzie na język angielski, [w:] Język dalekosiężny. Przekłady i międzynarodowa recepcja twórczości Zbigniewa Herberta, red. M. Heydel, E. Wójciek-Leese, M.Woźniak, Kraków 2010, s. 202.

${ }^{78}$ D. Weissbort, The Poetry of Survival. Post-War Poets of Central and Eastern Europe, Harmondsworth 1993, cyt. za: J. Jarniewicz, Przekleństwo przektadalności, czyli Herbert po angielsku, [w:] Język dalekosiężny, s. 17.

${ }^{79}$ A. Brajerska-Mazur, „Polityczność”, ,polskość” i ,uniwersalność”, s. 204.

80 S. Barańczak, Uciekinier z Utopii. O poezji Zbigniewa Herberta, wyd. 3, WarszawaWrocław 2001.

${ }^{81}$ Por.: P. Rosenau, Zbigniew Herbert - asor le-muto, s. 5; E. Hirsz, Zbigniew Herbert, Szirim.

${ }^{82}$ Z. Herbert, Selected Poems, thum. Cz. Miłosz, P. Dale Scott, wstęp A. Alvarez, Middlesex 1968, [za:] A. Brajerska-Mazur, „Polityczność”, ,polskość” $i$,, uniwersalność”, s. 203.

${ }^{83} \mathrm{~W}$ niniejszym artykule pominęłam część recenzji, których treść w dużym stopniu pokrywała się z innymi tekstami tego samego autora, a także te, które ograniczały się do analizy pojedynczych wierszy Herberta; por.: E. Miszori, Ani szo'ewet me-tochi [Czerpię z siebie], Jedijot Achronot 13.11.1998; D. Burstein, Sefer ha-szana szeli [Moja książka roku], Haarec 21.12.2005; E. Hirsz, Torat hamidot [Etyka], Jedijot achronot 18.01.2013; N. Kalderon, Nodedet olam, tamid bahira [Wędruje światem, wiecznie jasna], Haarec 20.03.2013.

${ }^{84}$ B. Tarnowska, Miłosz w Izraelu, s. 181.

${ }^{85}$ Por. słowa Dawida Weinfelda: „Muszę powiedzieć, że byłbym rad, gdyby ktoś inny mówił o tym. Problem polega na tym, że — jak mówi stare żydowskie powiedzenie — «Narzeczona jest za piękna», to znaczy, że thumacz nie mógłby sobie życzyć lepszej recepcji. Dlatego wolałbym, żeby ktoś inny, mniej zaangażowany, o tym mówił”; Z. Herbert, D. Weinfeld, Listy, s. 34. 


\section{LITERATURA}

Barańczak S., Uciekinier z Utopii. O poezji Zbigniewa Herberta, wyd. 3, Warszawa-Wrocław 2001 ;

Bozaglo Sz., Ma bejn ta'arubat le-tirkowet [Między mieszaniną a kombinacją], Maariw 6.01.2006, s. 26;

Brajerska-Mazur A., „Politycznośc”, ,polskość” $i$,, uniwersalnośc” wierszy Herberta w przektadzie na język angielski, [w:] Język dalekosiężny. Przektady i międzynarodowa recepcja twórczości Zbigniewa Herberta, red. M. Heydel, E. Wójciek-Leese, M. Woźniak, Kraków 2010, s. 202;

Bronowski J., Ha-realizm ha-holandi szel ha-szira ha-polanit [Holenderski realizm polskiej poezji], Haarec 31.10.1997, s. 2;

—, Machberet polanit: mi-Mickiewicz ad Herbert. Difduf mahir [Zeszyt polski: od Mickiewicza do Herberta. Szybki przeglad], Moznaim 1999 nr 4, s. 18-19;

—, Zbigniew Herbert, 1925(!)-1998, Haarec 30.07.1998, s. 3D;

Burstein D., Ruchot ha-refa'im szel chanujot sfarim, Mosaf Sfarim 4.10.2006, s. 16;

Dikman A., Lizkoro szel Mar Cogito [Pamięci Pana Cogito], Haarec 16.12.1998, s. 10;

Franaszek A., Pan Cogito, [w:] Herbert. Biografia, t. 2, Kraków 2018;

Gilboa J. A., Echad min „Ha-ja'ar Halochem” [Jeden z „Walczącego lasu”], Maariw 15.04.1977, s. 59C;

Gur B., Ha-ecem ha-jafe mi-kol hu ze sze'ejnenu [Najpiękniejszy jest przedmiot, którego nie ma], Haarec 10.07.1998, s. 14B;

Heaney S., Le-ruach ha-refa'im szel Zbigniew Herbert [Do ducha Zbigniewa Herberta], thum. na hebr. O. Peled; Iton 772008 nr 333-334, s. 11;

Herbert Z., Dotknąć rzeczywistości, [w:] tenże, ,Mistrz z Delft” $i$ inne utwory odnalezione, oprac. B. Toruńczyk, H. Citko, Warszawa 2008, s. 161;

Hirsz E., Dawid Weinfeld, Iwrut, michbar tirgumej szira [Dawid Weinfeld, Hebraizacja, wybór przekładów poezji], Jedijot Achronot 18.01.2013, http://elihirsh.com/?p=4641 [dostęp: 24.03.2018];

—, Michtaw hitabdut [List samobójcy], Jedijot Achronot 5.01.2015, https://www.yediot.co.il/ articles/0,7340,L-4748865,00.html [dostęp: 24.03.2017];

—, Zbigniew Herbert, Szirim, Jedijot Achronot 9.03.2012; http://elihirsh.com/?p=3607 [dostęp: 24.03.2018];

Itamar J., Philip Rosenau ose cheszbon: sicha [Philip Rosenau rozważa: rozmowa], Iton 772011 nr 353, s. 38;

Jarniewicz J., Przekleństwo przektadalności, czyli Herbert po angielsku, [w:] Język dalekosiężny. Przektady i międzynarodowa recepcja twórczości Zbigniewa Herberta, red. M. Heydel, E. Wójciek-Leese, M. Woźniak, Kraków 2010, s. 17;

Katz J., List z Kopenhagi, Znak 1997 nr 3 (502), s. 163-166;

Krynicki R., Od wydawcy, Kwartalnik Artystyczny nr 2 (62) 2009, s. 7;

Literatura polska w Izraelu. Leksykon, red. K. Famulska-Ciesielska, S. J. Żurek, KrakówBudapeszt 2012, s. 35, 40, 104, 144;

Maszaw M., Gmi'ot achadot le-atid [Kilka łyków za przyszłość], Maariw 13.04.1984, s. 38;

Miszol A., Ha-meridianim szel ha-sifrut [Meridiany literatury], Iton $772008 \mathrm{nr}$ 333-334, s. 33;

Or A., Sicha im Mar Cogito [Rozmowa z Panem Cogito], Iton 772008 nr 333-334, s. 11;

Reyzel M., Tachanat ruach [Wiatrak], Maariw 29.12.1989, s. SC6;

Ribner T., Le-zecher Zbigniew Herbert [Pamięci Zbigniewa Herberta], Iton 772008 nr 333-334, s. 11;

Rosenau P., Elegia le-mar Cogito [Elegia dla Pana Cogito], Iton 772008 nr 333-334;

—, Zbigniew Herbert - asor le-muto [Zbigniew Herbert — w dziesiątą rocznicę śmierci], Iton 772008 nr 333-334, s. 5;

Rozenfeld Sz., Meszorer hacham we-acuw [Poeta mądry i smutny], Maariw 6.12.1985, s. 23;

Schweizer E., Szirim szel Zbigniew Herbert: ed ohew [Wiersze Zbigniewa Herberta: czułego świadka], Haarec 13.02.2012, https://www.haaretz.co.il/literature/poetrybelongings/1.1636452 [dostęp: 24.03.2018];

Szetel Sz., Bone olam, lo me-atomim, ela me-sze'eriot [Świat buduje, nie z atomów, lecz z odłamków], Iton 77 2006, nr 312-313, s. 11; 
Szternfeld C., Intimiut im ha-necach [Intymność z wiecznością], Iton 772008 nr 333-334, s. 46; Tarnowska B., Miłosz w Izraelu (rekonesans), Świat i Słowo 2015 nr 2 (25), s. 165-182;

Vizan J., Popolonizm: lama ha-szira ha-polanit ha-meturgemet mazika la-szira ha-iwrit haachszawit [Popolonizm: dlaczego tłumaczenia poezji polskiej szkodzą współczesnej poezji hebrajskiej], Haarec 27.09.2019, https://www.haaretz.co.il/literature/poetry/.premiumREVIEW-1.7889412 [dostęp: 12.12.2019];

Weichert R., Ha-bituj ha-medujak la-achzarjut ha-enoszit [Dokładne określenie ludzkiego okrucieństwa], Maariw 18.09.1998, s. 37;

Weinfeld D., Ha-dimiun ha-mehapes et ha-seder: al szirato szel Zbigniew Herbert [Wyobraźnia szukająca porządku: o poezji Zbigniewa Herberta], Moznaim $1983 \mathrm{nr}$ 5, s. 34-36;

-, Ha-metargemim ha-meatim mi-iwrit ma'adifim letargem proza: ra'ajon im Ryszard Krynicki [Nieliczni thumacze z hebrajskiego wolą thumaczyć prozę: wywiad z Ryszardem Krynickim], Iton 772009 nr 337-338, s. 30.

\section{MISTER COGITO THINKS IN HEBREW. ON THE RECEPTION OF ZBIGNIEW HERBERT'S POETRY IN ISRAEL}

The aim of this article is to present the reception of Zbigniew Herbert's work in Israel. Since the release of the first collection of poems in 1984 up until 2019, Hebrew translations of Herbert's poetry were included in five poetry collections, three anthologies of Polish poetry, and also in many literary periodicals and daily newspapers. Over the next decades such characteristics of Herbert's writings as classic equilibrium of style, contemplativeness, restraint and irony attracted the attention of Israeli critics and poets. The most important promoter of Herbert's poetry in Israel is translator David Weinfeld whose translations have been appreciated for their faithfulness to the original, concern for comprehensibility and poetic prominence. It was due to David Weinfeld's translations that the writings of the author of Mr Cogito-next to Czesław Miłosz's and Wislawa Szybmorska's poetry - have inspired many Israeli poets.

KEYWORDS: Zbigniew Herbert; Polish poetry in Israel; Polish poetry in translation; Hebrew translations.

\section{PAN COGITO MYŚLI PO HEBRAJSKU. O RECEPCJI POEZJI ZBIGNIEWA HERBERTA W IZRAELU}

Celem niniejszego artykułu jest przedstawienie recepcji twórczości Zbigniewa Herberta w Izraelu. Od momentu wydania tam w 1984 r. pierwszego tomiku wierszy, aż do 2019 r., poezja Herberta w przekładach na język hebrajski prezentowana była w pięciu książkowych zbiorach wierszy, w trzech antologiach poezji polskiej, a także w licznych czasopismach literackich oraz w prasie codziennej. Takie cechy utworów Herberta jak klasyczna równowaga stylu, kontemplacyjność, powściągliwość oraz ironia przez kolejne dziesięciolecia przyciągały uwagę zarówno izraelskich krytyków, jak i poetów. Najważniejszym propagatorem poezji Herberta w Izraelu jest thumacz Dawid Weinfeld, którego wysokiej próby przekłady zostały docenione w równym stopniu za zachowanie wierności wobec oryginału, jak i dbałość o zrozumiałość oraz oddanie kunsztu poetyckiego. Przekłady Weinfelda sprawiły, że twórczość autora Pana Cogito, obok wierszy Czesława Miłosza i Wisławy Szymborskiej, stała się ważną inspiracją dla wielu izraelskich poetów.

SŁOWA KLUCZOWE: Zbigniew Herbert; polska poezja w Izraelu; polska poezja w przekładzie; thumaczenia hebrajskie. 